\title{
Phylogenetic analysis of psychrophilic bacteria isolated from the Japan Trench, including a description of the deep-sea species Psychrobacter pacificensis sp. nov.
}

\author{
Akihiko Maruyama, ${ }^{1}$ Daiske Honda, $\dagger^{1,2}$ Hiroyuki Yamamoto, ${ }^{3}$ \\ Keiko Kitamura ${ }^{1}$ and Takanori Higashihara ${ }^{1}$
}

1 National Institute of Bioscience and HumanTechnology, Tsukuba, Ibaraki 305-8566, Japan

2 Marine Biotechnology Institute Co. Ltd, Kamaishi, Iwate 026-0001, Japan

3 St Marianna University School of Medicine, Kawasaki, Kanagawa 216-8511, Japan

\author{
Author for correspondence: Akihiko Maruyama. Tel: +81 29861 6062. Fax: +81 298616412 \\ e-mail: maruyama@nibh.go.jp
}

\begin{abstract}
Phylogenetic positions of psychrophilic bacteria isolated from the Japan Trench were determined by sequencing analysis of PCR-amplified bacterial small subunit (16S) rRNA genes. Between surface and deep-sea psychrophiles, distinct positions clearly differed within the $\gamma$-Proteobacteria. In phylogenetic analysis using neighbour-joining, maximum-parsimony and maximumlikelihood, strains from surface seawater were inferred to be located in the Halomonas aquamarina-meridiana clade within the family Halomonadaceae. Strains from deep seawater (5000-6000 m), however, formed a novel monophyletic clade within the Moraxella-Psychrobacter branch in the family Moraxellaceae, showing separation from terrestrial and Antarctic relatives. These deep-sea strains were also discriminated from other known Psychrobacter species in phenotype, e.g. limited growth in the absence of $\mathrm{NaCl}$ (optimum at about $3 \% \mathrm{NaCl}$ ), positive urease activity, acid production from xylose and arabinose, and the presence of multiple fimbriae. DNA relatedness values among six deep-sea strains were $>85 \%$ in DNA-DNA hybridization experiments and $>98 \%$ in aligned 165 rDNA sequences. From this evidence, a new species, Psychrobacter pacificensis, is proposed for these deep-sea psychrophiles; the type strain of Psychrobacter pacificensis is strain NIBH P2K6 $^{\mathrm{T}}$ ( = IFO 16270'). Occurrence of psychrobacters in cold Japan Trench deep seawater and at the Antarctic sea surface suggests that deep-sea bacterial habitation and evolution have been mediated by global deep-ocean circulation linked to the sinking of cooled seawater in polar regions.
\end{abstract}

Keywords: marine bacteria, psychrophiles, Psychrobacter pacificensis, Moraxella, Halomonas

\section{INTRODUCTION}

Most bacteria found in surface to deep marine environments remain to be characterized because of difficulties in cultivation and isolation. Knowledge on the origins and habitats of even culturable microbes is still limited, especially for those from the deep ocean. †resent address: Faculty of Science, Konan University, 8-9-1 Okamoto,
Higashinada, Kobe, Hyogo 658-8501, Japan.

Abbreviations: ML, maximum-likelihood; MP, maximum-parsimony; NJ, neighbour-joining; PNPG, $p$-nitrophenyl $\beta$-D-galactopyranoside.
These microbes appear to have adapted to or survived in deep-sea environments under physico-chemical parameters that differ from those at the ocean surface, e.g. dark, cold, high pressure, relatively stable salinity and richness in inorganic nutrients but ordinarily a paucity of organic nutrients.

Many psychrophilic bacteria, which grow at as low as $4{ }^{\circ} \mathrm{C}$ and at more than $20^{\circ} \mathrm{C}$, have been previously isolated from the surface and deep-sea environments of the Japan Trench (Maruyama et al., 1997). These psychrophiles appear to be distributed in various marine environments, although their predominance differs in the Antarctic (Simidu et al., 1986), ocean 
Table 1. Bacterial species, strains, sources and $16 \mathrm{~S}$ rDNA sequence information

\begin{tabular}{|c|c|c|c|}
\hline Species & Strain* & $\begin{array}{l}\text { Sequence accession } \\
\text { number (length) }\end{array}$ & Original source and other names \\
\hline \multicolumn{4}{|l|}{$\begin{array}{l}\text { Halomonadaceae and } \\
\text { related species }\end{array}$} \\
\hline Halomonas aquamarina & ATCC $14400^{\mathrm{T}}$ & M93352 (1466 bp) & $\begin{array}{l}\text { 'Achromobacter aquamarinus', } \\
\text { 'Deleya aquamarina' }\end{array}$ \\
\hline Halomonas cupida & DSM $4740^{T}$ & L42615 (1471 bp) & 'Deleya cupida' \\
\hline Halomonas elongata & ATCC $33173^{\mathrm{T}}$ & M93355 (1479 bp) & \\
\hline Halomonas halmophila & ATCC $19717^{\mathrm{T}}$ & M59153 (1540 bp) & 'Flavobacterium halmephilum' \\
\hline Halomonas halodenitrificans & ATCC $13511^{\mathrm{T}}$ & L04942 (1531 bp) & 'Paracoccus halodenitrificans' \\
\hline Halomonas halodurans & DSM $5160^{T}$ & L42619 (1474 bp) & \\
\hline Halomonas halophila & DSM $4770^{T}$ & M93353 (1453 bp) & 'Deleya halophila' \\
\hline Halomonas marina & ATCC $25374^{\mathrm{T}}$ & M93354 (1446 bp) & $\begin{array}{l}\text { 'Arthrobacter marinus', 'Deleya } \\
\text { marina' }\end{array}$ \\
\hline Halomonas meridiana & DSM $5425^{\mathrm{T}}$ & M93356 (1475 bp) & \\
\hline Halomonas pacifica & DSM $4742^{\mathrm{T}}$ & L42616 (1480 bp) & 'Deleya pacifica' \\
\hline Halomonas pantelleriensis & AAP & X93493 (1477 bp) & \\
\hline Halomonas salina & ATCC $49509^{\mathrm{T}}$ & X87217 (1478 bp) & 'Deleya salina' \\
\hline Halomonas subglaciescola & DSM $4683^{\mathrm{T}}$ & M93358 (1481 bp) & \\
\hline Halomonas variabilis & DSM $3051^{\mathrm{T}}$ & M93357 (1470 bp) & 'Halovibrio variabilis' \\
\hline Halomonas venusta & DSM $4743^{T}$ & L42618 (1479 bp) & 'Deleya venusta' \\
\hline Marinomonas vaga & ATCC $27119^{\mathrm{T}}$ & X67025 (1467 bp) & $\begin{array}{l}\text { 'Alteromonas vaga', } \\
\text { 'Oceanospirillum vagum' }\end{array}$ \\
\hline Oceanospirillum linum & ATCC $11336^{\mathrm{T}}$ & M22365 (1517 bp) & \\
\hline Halomonas eurihalina & ATCC $49336^{\mathrm{T}}$ & L42620 (1490 bp) & 'Volcaniella eurihalina' \\
\hline Zymobacter palmae & $\mathrm{T} 109$ & D14555 (1503 bp) & \\
\hline Halomonas sp. & NIBH P1H8 & AB016049 (1517 bp) & $\begin{array}{l}\text { Japan Trench surface seawater } \\
\text { (Station } \mathrm{P} 1 ; 0 \mathrm{~m})\end{array}$ \\
\hline Halomonas sp. & NIBH P1H13 & AB016050 (1525 bp) & $\begin{array}{l}\text { Japan Trench surface seawater } \\
\text { (Station } \mathrm{P} 1 ; 0 \mathrm{~m})\end{array}$ \\
\hline Halomonas sp. & NIBH P1H14 & AB016051 (1526 bp) & $\begin{array}{l}\text { Japan Trench surface seawater } \\
\text { (Station } \mathrm{P} 1 ; 0 \mathrm{~m})\end{array}$ \\
\hline Halomonas sp. & NIBH P1H22 & AB016052 (1528 bp) & $\begin{array}{l}\text { Japan Trench surface seawater } \\
\text { (Station } \mathrm{P} 1 ; 0 \mathrm{~m})\end{array}$ \\
\hline Halomonas sp. & NIBH P1H25 & AB016053 (1519 bp) & $\begin{array}{l}\text { Japan Trench surface seawater } \\
\text { (Station } \mathrm{P} 1 ; 0 \mathrm{~m})\end{array}$ \\
\hline \multicolumn{4}{|l|}{ Moraxellaceae } \\
\hline 'Acinetobacter anitratus' & ATCC 15308 & U10874 (1528 bp) & $\begin{array}{l}\text { 'Acinetobacter anitratum', } \\
\text { Acinetobacter baumannii }\end{array}$ \\
\hline Acinetobacter baumannii & DSM $30007^{T}$ & X81660 (1459 bp) & 'Bacterium anitratum' \\
\hline Acinetobacter calcoaceticus & 33604 & M34139 (1536 bp) & $\begin{array}{l}\text { 'Moraxella calcoacetica', } \\
\text { 'Neisseria winogradskyi', } \\
\text { 'Micrococcus calcoaceticus', } \\
\text { Acinetobacter } \text { sp. }\end{array}$ \\
\hline Acinetobacter haemolyticus & DSM $6962^{\mathrm{T}}$ & X81662 (1460 bp) & \\
\hline Acinetobacter johnsonii & DSM $6963^{T}$ & X81663 (1460 bp) & \\
\hline Acinetobacter junii & DSM 1532 & X81658 (1459 bp) & \\
\hline Acinetobacter lwoffii & ATCC 17925 & U10875 (1538 bp) & 'Acinetobacter lwoffi' \\
\hline Acinetobacter radioresistens & DSM $6976^{\mathrm{T}}$ & X81666 (1459 bp) & \\
\hline Moraxella catarrhalis & ATCC $25238^{\mathrm{T}}$ & U10876 (1511 bp) & 'Branhamella catarrhalis' \\
\hline Moraxella lacunata & ATCC $17967^{\mathrm{T}}$ & D64049 (1519 bp) & \\
\hline Psychrobacter frigidicola & ACAM $304^{\mathrm{T}}$ & U46143 (1484 bp) & Antarctic ornithogenic soil \\
\hline Psychrobacter glacincola & ACAM $483^{\mathrm{T}}$ & $\mathrm{U} 46145$ (1467 bp) & $\begin{array}{l}\text { Antarctic sea ice; 'Psychrobacter } \\
\text { endoglaciecola' }\end{array}$ \\
\hline Psychrobacter immobilis & ATCC $43116^{\mathrm{T}}$ & U39399 (1477 bp) & $\begin{array}{l}\text { Seawater, fish, pork sausage, } \\
\text { ground beef, etc. }\end{array}$ \\
\hline
\end{tabular}


Table 1 (cont.)

\begin{tabular}{|c|c|c|c|}
\hline Species & Strain* & $\begin{array}{c}\text { Sequence accession } \\
\text { number (length) }\end{array}$ & Original source and other names \\
\hline Psychrobacter immobilis & ACAM 286 & U46139 (1476 bp) & Antarctic ornithogenic soil \\
\hline Psychrobacter phenylpyruvicus & $\begin{array}{l}\operatorname{ATCC} 23333^{\mathrm{T}}(=\mathrm{ACAM} \\
\left.535^{\mathrm{T}}\right)\end{array}$ & $\mathrm{U} 46144(1433 \mathrm{bp})$ & $\begin{array}{l}\text { Blood; 'Moraxella } \\
\text { phenylpyruvica', 'Psychrobacter } \\
\text { phenylpyruvicum, }\end{array}$ \\
\hline Psychrobacter urativorans & $\begin{array}{l}\operatorname{ACAM~} 534^{\mathrm{T}}(=\mathrm{ATCC} \\
\left.15174^{\mathrm{T}}\right)\end{array}$ & U46141 (1485 bp) & $\begin{array}{l}\text { Pork sausage; 'Micrococcus } \\
\text { cryophilus', 'Psychrobacter } \\
\text { uratovorans', }\end{array}$ \\
\hline Psychrobacter pacificensis & NIBH P2J2 & AB016054 (1536 bp) & $\begin{array}{l}\text { Japan Trench deep seawater } \\
\text { (Station P2; } 5000 \mathrm{~m})\end{array}$ \\
\hline Psychrobacter pacificensis & NIBH P2J3 & AB016055 (1531 bp) & $\begin{array}{l}\text { Japan Trench deep seawater } \\
\text { (Station P2;5000 m) }\end{array}$ \\
\hline Psychrobacter pacificensis & NIBH P2J13 & AB016056 (1525 bp) & $\begin{array}{l}\text { Japan Trench deep seawater } \\
\text { (Station P2; } 5000 \mathrm{~m})\end{array}$ \\
\hline Psychrobacter pacificensis & $\begin{array}{l}\text { NIBH P2K6 } 6^{\mathrm{T}}(=\mathrm{IFO} \\
\left.16270^{\mathrm{T}}\right)\end{array}$ & AB016057 (1526 bp) & $\begin{array}{l}\text { Japan Trench deep seawater } \\
\text { (Station P2;6000 m) }\end{array}$ \\
\hline Psychrobacter pacificensis & NIBH P2K17 & AB016058 (1530 bp) & $\begin{array}{l}\text { Japan Trench deep seawater } \\
\text { (Station P2;6000 m) }\end{array}$ \\
\hline Psychrobacter pacificensis & NIBH P2K18 & AB016059 (1520 bp) & $\begin{array}{l}\text { Japan Trench deep seawater } \\
\text { (Station P2;6000 m) }\end{array}$ \\
\hline \multicolumn{4}{|l|}{ Others } \\
\hline Bacillus subtilis & 168 & D26185 (1553 bp) & \\
\hline Escherichia coli & Unknown & J01695 (1542 bp) & \\
\hline Pseudomonas aeruginosa & DSM $50071^{\mathrm{T}}$ & X06684 (1537 bp) & \\
\hline Pseudoalteromonas sp. & NIBH PS2M11 & AB016267 (1522 bp) & $\begin{array}{l}\text { Japan Trench deep-sea sediment } \\
\text { (Station PS2;3569 m) }\end{array}$ \\
\hline Pseudoalteromonas $\mathrm{sp}$. & NIBH PS1M3 & AB016268 (1524 bp) & $\begin{array}{l}\text { Japan Trench deep-sea sediment } \\
\text { (Station PS1;5974 m) }\end{array}$ \\
\hline Bacillus sp. & NIBH PS3M5 & AB016269 (1542 bp) & $\begin{array}{l}\text { Japan Trench deep-sea sediment } \\
\text { (Station PS3;2169 m) }\end{array}$ \\
\hline Bacillus sp. & NIBH PS3M26 & AB016270 (1540 bp) & $\begin{array}{l}\text { Japan Trench deep-sea sediment } \\
\text { (Station PS3;2169 m) }\end{array}$ \\
\hline Vibrio sp. & NIBH P2K5 & AB016271 (1533 bp) & $\begin{array}{l}\text { Japan Trench deep seawater } \\
\text { (Station P2;6000 m) }\end{array}$ \\
\hline
\end{tabular}

* ATCC, American Type Culture Collection, Manassas, VA, USA; DSM, Deutsche Sammlung von Mikroorganismen, Braunschweig, Germany; ACAM, Australian Collection of Antarctic Micro-organisms, University of Tasmania, Australia; NIBH, National Institute of Bioscience \& Human-Technology, Tsukuba, Japan; IFO, Institute for Fermentation, Osaka, Japan.

upwelling (Rüger, 1989) and hydrothermal environments (Maruyama et al., 1993). From growth-temperature experiments with psychrophilic bacteria from the Japan Trench, higher degrees of psychrophily were generally found in deep-sea strains than in surface strains (Maruyama et al., 1997). These marine psychrophiles were also characterized by an abundance of Moraxella-like bacteria, especially in deep seawater. RFLP analysis of bacterial 16S rRNA genes suggests that these deep-sea Moraxella-like bacteria are not assignable to representative species in the genera Moraxella and Psychrobacter of the family Moraxellaceae (Maruyama et al., 1997).

Moraxella-like bacteria characterized by Gram-negative, aerobic, oxidase-positive, non-motile and nonpigmented coccobacilli have been isolated from natural environments and cold-storage meat products such as fish, poultry, lamb and beef (Juni \& Heym, 1980, 1986; Maruyama et al., 1986, 1990; Prieto et al., 1992; Shaw \& Latty, 1988; Shewan et al., 1960; Simidu et al., 1977, 1980). Among these, psychrophilic moraxellas, previously termed Achromobacter, have been classified in the genus Psychrobacter (Juni \& Heym, 1986). In addition to the genospecies Psychrobacter immobilis, Bowman et al. $(1996,1997)$ recently proposed some new species of Antarctic origin, i.e. Psychrobacter urativorans and Psychrobacter frigidicola from Antarctic ornithogenic soils and Psychrobacter glacincola from Antarctic sea ice, indicating that members of the genus Psychrobacter are widespread in cold Antarctic environments.

Some members of the genera Halomonas, Deleya and Halovibrio in the family Halomonadaceae that are characterized by aerobic, motile or non-motile, mod- 


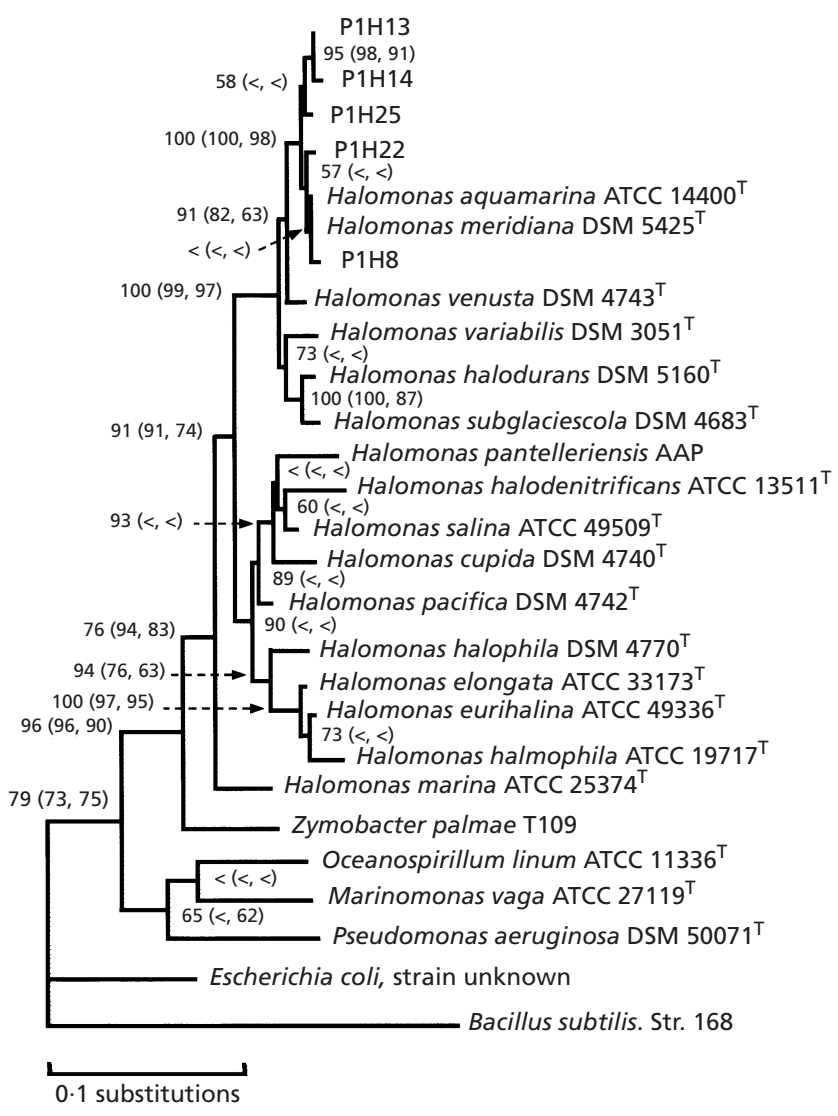

Fig. 1. Phylogenetic relatedness between psychrophilic bacteria from surface seawater and members of the family Halomonadaceae. The phylogenetic tree was inferred by $\mathrm{ML}$ using a gap-free aligned 165 rDNA sequence profile (27 operational taxonomic units, total $1036 \mathrm{nt}$ ). The alpha/beta parameter was set at $2 \cdot 158$. Bootstrap probabilities less than $50 \%$ are shown by ' $<$ ' and those estimated by NJ and MP are given in parentheses, e.g. ML (NJ, MP). Bacillus subtilis was used as an outgroup taxon.

erately or strictly halophilic, Gram-negative rods (Holt et al., 1994) may be assigned as Moraxella-like in diagnostic identification. Since difficulties exist in differentiating these genera using chemotaxonomic and phylogenetic parameters, Dobson \& Franzmann (1996) recently proposed unification of the genera Deleya, Halomonas and Halovibrio and the species Paracoccus halodenitrificans into a single genus, Halomonas. Although little data on their psychrophily exists, it is plausible that some non-motile Halomonas members have been identified as Moraxella-like bacteria among heterotrophs culturable at temperatures below $10^{\circ} \mathrm{C}$.

The genus Moraxella was established with bacteria isolated from warm-blooded animals (Krieg \& Holt, 1984), but more attention must be paid to these Moraxella-like bacteria because of their wide distribution in natural and artificial environments from cold to moderate temperatures. In this study, phylogenetic positions of psychrophilic moraxellas of oceanic-surface and deep-sea origins were defined, their motility was cross-checked and appendages were observed. Together with phenotypic and chemotaxonomic results, a new species, Psychrobacter pacificensis, is proposed for these psychrophilic moraxellas of deep-sea origin.

\section{METHODS}

Bacterial strains. The 16 strains studied were selected from 67 strains isolated from surface and deep-sea environments of the Japan Trench (Table 1); of these, 11 were tentatively identified as Moraxella-like bacteria. They were purified on different agar media including artificial-seawater-based 1/2 $\mathrm{TZ}$ containing polypeptone and yeast extracts (Maruyama et al., 1993), marine agar 2216 (Difco) and nutrient agar (Difco). Each strain was incubated at $20^{\circ} \mathrm{C}$ and cells in the middle to late exponential growth phases were used for experiments unless otherwise noted. A $1 / 2 \mathrm{TZ}$ semi-solid agar medium containing $0.3 \%$ agar instead of the original concentration of $1.5 \%$ was used for preservation at $4{ }^{\circ} \mathrm{C}$. For long-term preservation, cells were suspended in a sterilized $1 / 2 \mathrm{SW}$ preservative $[12 \%(\mathrm{w} / \mathrm{v})$ sucrose, $50 \%$ (v/v) horse serum and $50 \%(\mathrm{v} / \mathrm{v})$ aged seawater], dried from the liquid state in an aseptic glass tube under a vacuum at room temperature, enclosed in the tube under the vacuum, and stored at $4{ }^{\circ} \mathrm{C}$ (Suzuki \& Yamasato, 1986).

DNA sequencing and alignment. For Moraxella-like strains isolated from deep seawater, the sequence of the $16 \mathrm{~S}$ rRNA gene was determined as follows. Cells were harvested by centrifugation, washed and resuspended in TE buffer (10 mM Tris/HCl, 1 mM EDTA; pH 8.0). Genomic DNA was extracted by a standard protocol using cetyltrimethylammonium bromide, phenol, chloroform and isoamyl alcohol (Murray \& Thompson, 1980). PCR for the almost complete 16S rRNA gene was conducted by GeneAmp PCR 9600 (Perkin-Elmer) using primers 27f and 1525r (Lane, 1991) and a previously described PCR cycle (Maruyama et al., 1997). Excess primers and dNTP were removed from PCR products using Suprec 02 (Takara). Purified PCR products were sequenced directly by an automated DNA sequencer (ALFred; Pharmacia) in cycle sequencing according to the manufacturer's instructions, using appropriate forward and reverse primers (Lane, 1991): 342r, 359f (5'-TCC TAC GGG AGG CAG CAG TG; 20-mer), 519r, 803r (5'-CAT CGT TTA CGG CGT GGA C; 19-mer), 821f (5'-GTC CAC GCC GTA AAC GAT G; 19-mer), 1104r (5'TTG CGC TCG TTG CGG GAC; 18-mer) and 1111f (5'-GTC CCG CAA CGA GCG CAA; 18-mer) in the Escherichia coli numbering system. Sequences for each fragmental 16S rDNA region were determined over both strands and were connected by GENETYX software (version 8 ; Software Development). Except for deep-sea strains, bacterial 16S rDNA was extracted, amplified and subcloned as described previously (Maruyama et al., 1997). Sequences were aligned using a multiple alignment program in CLUSTAL W (version 1.71; Thompson et al., 1994). Our determined sequences were fitted to known aligned sequences obtained from the rRNA server at the University of Antwerp (http://rrna.uia.ac.be/; Van de Peer et al., 1997) using a CLUSTAL $\mathrm{w}$ profile alignment option. From this aligned data matrix, all positions with gaps, i.e. undetermined and ambiguous sequences, were removed. The plain, aligned sequence data set was then used for phylogenetic analysis. Species names, accession numbers and sequence lengths used are shown in Table 1. 
Table 2. Motility and appendages of psychrophilic bacteria from surface and deep seawater in the Japan Trench

\begin{tabular}{|c|c|c|c|c|}
\hline \multirow[t]{2}{*}{ Strain } & \multicolumn{2}{|c|}{ Motility* } & \multirow[t]{2}{*}{ Appendage $\dagger$} & \multirow[t]{2}{*}{ Phylogenetic location } \\
\hline & Microscopic & Agar plate & & \\
\hline \multicolumn{5}{|c|}{ Surface seawater } \\
\hline P1H8 & - & - & Flagella: & Halomonadaceae \\
\hline P1H13 & - & - & None & Halomonadaceae \\
\hline $\mathrm{P} 1 \mathrm{H} 14$ & - & - & None & Halomonadaceae \\
\hline $\mathrm{P} 1 \mathrm{H} 22$ & + & + & Flagella & Halomonadaceae \\
\hline $\mathrm{P} 1 \mathrm{H} 25$ & + & + & Flagella & Halomonadaceae \\
\hline \multicolumn{5}{|c|}{ Deep seawater } \\
\hline $\mathrm{P} 2 \mathrm{~J} 2$ & $-/ \mathrm{w}$ & - & Fimbriae & Moraxellaceae \\
\hline $\mathrm{P} 2 \mathrm{~J} 3$ & $-/ \mathrm{w}$ & - & Fimbriae & Moraxellaceae \\
\hline P2J13 & $-/ \mathrm{w}$ & - & Fimbriae & Moraxellaceae \\
\hline $\mathrm{P} 2 \mathrm{~K} 6^{\mathrm{T}}$ & $-/ \mathrm{w}$ & - & Fimbriae & Moraxellaceae \\
\hline $\mathrm{P} 2 \mathrm{~K} 17$ & $-/ \mathrm{w}$ & - & Fimbriae & Moraxellaceae \\
\hline P2K 18 & $-/ w$ & - & Fimbriae & Moraxellaceae \\
\hline
\end{tabular}

* Microscopic motility was assessed by light microscopy with Nomarski apparatus; agar plate motility was assessed on semi-solid agar plates with nutrient gradient. - , Negative; +, positive; w, weak twitching motility.

$\dagger$ EM observation.

\$ Flagellum attachment was occasionally observed.

Phylogenetic analysis. Maximum-likelihood (ML; Felsenstein, 1981), neighbour-joining (NJ; Saitou \& Nei, 1987) and maximum-parsimony (MP; Fitch, 1971) were used to construct phylogenetic trees. ML analysis was implemented with NUCML and NJDIST programs in MOLPHY (version 2.3b; Adachi \& Hasegawa, 1996). Using a distance matrix estimated by ML, an NJ tree was first inferred as the starting tree. The NJ tree was then analysed by local rearrangement (Adachi \& Hasegawa, 1996) using the HKY85 model (Hasegawa et al., 1985) to search for the ML tree. NJ was analysed using Kimura's two-parameter procedure (Kimura, 1980) and PHYLIP software (version 3.57c; Felsenstein, 1995). MP was analysed by a heuristic search with options of random stepwise addition (100 replicates), a tree-bisectionreconnection branch swapping algorithm, and MULPARS, using PAUP* (test version 4.0d63; David L. Swofford). A strict consensus tree was selected from 35 equal parsimonious trees in Halomonadaceae analysis or 40 equal ones in Moraxellaceae analysis. The statistical significance of tree branches was assessed by bootstrap analysis involving the construction of 1000 trees from resampled data in NJ and 100 trees in MP. All ML, NJ and MP trees were further analysed by NUCML and the best ML tree with the highest likelihood and the lowest estimate of Akaike's information criterion (Akaike, 1974) was selected. Local bootstrap probabilities in the best ML tree were calculated by resampling estimated log-likelihood (Hasegawa \& Kishino, 1994; Kishino et al., 1990).

DNA-DNA hybridization. Bacterial DNA was purified by the general extraction method using phenol mixture [phenol, chloroform and 3-methyl-1-butanol (25: 24:1)] and ethanol. To increase DNA purity, cells in TE buffer were also pretreated with lysozyme $\left(0 \cdot 1 \mathrm{mg} \mathrm{ml}^{-1}\right)$ and $3 \%$ SDS at $60{ }^{\circ} \mathrm{C}$ for $10 \mathrm{~min}$. After extraction, the ethanol precipitate was treated with RNase A $\left(10 \mu \mathrm{g} \mathrm{ml}^{-1}\right)$ at $35^{\circ} \mathrm{C}$ for $30 \mathrm{~min}$, incubated with proteinase $\mathrm{K}\left(10 \mu \mathrm{g} \mathrm{ml}^{-1}\right)$ and $0.3 \% \mathrm{SDS}$ at
$50{ }^{\circ} \mathrm{C}$ for $60 \mathrm{~min}$, and purified again. Purified DNA was then dissolved in TE buffer, immobilized on a microplate (Ezaki et al., 1989) and labelled using a photoactivatable form of biotin (PHOTOPROBE Long Arm Biotin, SP-1020; Vector Laboratories). The relative relatedness among the DNA samples was determined by colorimetric microplate hybridization (Kusunoki et al., 1991). Blocking solution $[2 \times \mathrm{SSC}$ ( $0.3 \mathrm{M} \mathrm{NaCl}, 0.03 \mathrm{M}$ sodium citrate) containing $2 \%$ blocking reagent (Roche Diagnostics)] was added to DNA plate wells and kept at room temperature for $30 \mathrm{~min}$. After discarding this, $100 \mu \mathrm{l}$ hybridization solution $(2 \times \mathrm{SSC}, 50 \%$

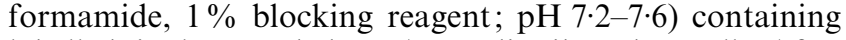
labelled single-stranded DNA was distributed to wells. After $16 \mathrm{~h}$ hybridization at $55^{\circ} \mathrm{C}$, wells were washed three times with $1 \times \mathrm{SSC}$ solution. Alkaline phosphatase-streptavidin (Vector Laboratories) was diluted 1000 times with PBS $(-)$ (sodium chloride, $8 \mathrm{~g}$; potassium chloride, $0.2 \mathrm{~g}$; disodium phosphate, $1 \cdot 15 \mathrm{~g}$; monopotassium phosphate, $0 \cdot 20 \mathrm{~g}$; distilled water, $1000 \mathrm{ml}$; $\mathrm{pH}$ 7·3-7·6) containing blocking agent (Block Ace TM Powder; Dai Nippon Seiyaku), and $100 \mu \mathrm{l}$ of the dilution was distributed to wells. After $30 \mathrm{~min}$ incubation at $35^{\circ} \mathrm{C}$, wells were washed three times with $\operatorname{PBS}(-)$ and filled with $100 \mu \mathrm{l}$ substrate solution (BluePho TM Microwell Phosphatase Substrate system; Kirkegaard \& Perry Laboratories). The plate was incubated at room temperature and the $A_{630}$ value of each well was measured. Homology values among strains were calculated from triplicate DNA-DNA hybridization experiments.

Motility tests and microscopic observation. Bacterial cells in the early exponential growth phase were used for motility tests. Bacterial motility was observed under a microscope (Axiophot; Zeiss) using Nomarski differential interference contrast. Motility was also tested on a semi-solid agar plate made by pouring plain agar containing $0.3 \%$ purified agar 


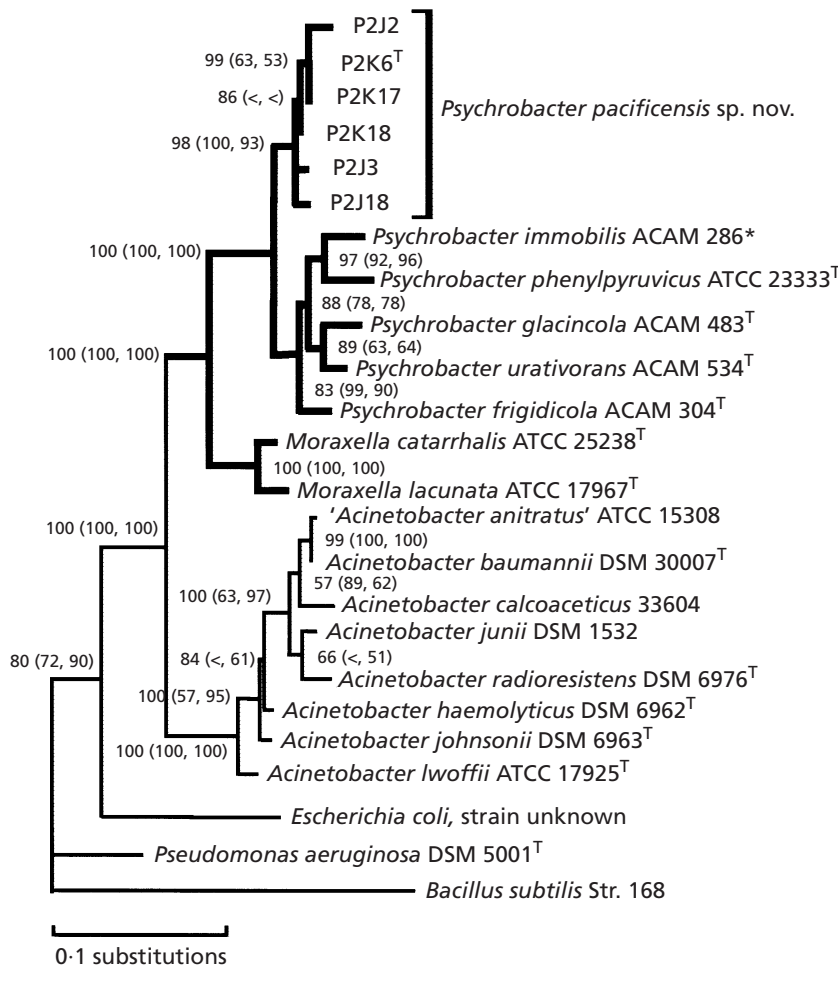

Fig. 2. Phylogenetic relatedness between psychrophilic bacteria from deep seawater and members of the family Moraxellaceae. The phylogenetic tree was inferred by ML using a gap-free aligned $16 \mathrm{~S}$ rDNA sequence profile (24 operational taxonomic units, total $1174 \mathrm{nt}$ ). The alpha/beta parameter was set at $2 \cdot 152$. Bootstrap probabilities less than $50 \%$ are shown by ' $<$ ' and those estimated by NJ and MP are given in parentheses, e.g. ML (NJ, MP). Bacillus subtilis was used as an outgroup taxon. Thicker lines show the Moraxella-Psychrobacter branch. *, The same phylogenetic position as P. immobilis ATCC $43116^{\top}$.

(Difco) and 90\% artificial seawater (Kester et al., 1967) onto small amounts of marine agar 2216 (Difco) solidified at the corner of a sterilized plate. Cells were inoculated onto the semi-solid agar surface $3-4 \mathrm{~cm}$ from the nutrient-rich corner and incubated at both 4 and $20^{\circ} \mathrm{C}$. For electron microscopic observation, cells were fixed with $5 \%(\mathrm{v} / \mathrm{v})$ glutaraldehyde (TAAB) in HM buffer (100 mM HEPES, $2 \mathrm{mM} \mathrm{MgCl}_{2}$; $\mathrm{pH} 6 \cdot 8$ ) and resuspended in $3 \% \mathrm{NaCl}$ solution. Alternatively, fixed cells were harvested by slow centrifugation at $2000-2300 \mathrm{~g}$ for $5 \mathrm{~min}$ and washed with pure water, recentrifuged, then a small portion of cell pellets was resuspended with pure water. The cell suspension was mixed with an equal volume of $5 \%$ glutaraldehyde in $0.2 \mathrm{M}$ cacodylate buffer. Cells were finally placed on EM grids covered with polyvinyl Formvar film, treated with a drop of $1 \%$ uranyl acetate for negative staining and dried at room temperature. A Hitachi H-7000 EM was used to observe bacterial cells and their appendages.

Phenotypic tests. Phenotypic tests for key taxonomic items such as Gram reaction, oxidase, catalase, glucose fermentation and acidification of carbohydrates were examined based on a standard manual (Smibert \& Krieg, 1994). Nitrate reduction and urease activity were determined by the method of Yamasato et al. (1982). Phenylalanine and tryptophan deaminase were determined according to Bøvre \& Henriksen (1976). Tolerance to different concentrations of $\mathrm{NaCl}$ was defined at $20^{\circ} \mathrm{C}$ on $1 / 2 \mathrm{TZ}$ agar medium, which replaced artificial seawater with pure water. The API $20 \mathrm{NE}$ system (bioMérieux) was used for tests of oxidase, nitrate reduction, indole production, glucose fermentation, arginine dihydrolase, urease, aesculin decomposition, gelatin hydrolysis and $\beta$-galactosidase using $p$-nitrophenyl $\beta$-D-galactopyranoside (PNPG), and the use of different substrates as sole carbon and energy sources. Substrate use was also determined by the API ID 32GN system (bioMérieux).

Fatty acid, quinone and GC content analyses. Cells were hydrolysed and methylated with methanol containing $5 \%$ $\mathrm{HCl}$ and fatty acids were extracted with n-hexane. Fatty acid profiles were determined with a GC (GC-14A; Shimadzu) having a methyl silicone-coated capillary column $(0.25 \mathrm{~mm}$ in diameter, $15 \mathrm{~m}$ long, $0.25 \mu \mathrm{m}$ depth of film) and a flameionization detector under increasing temperatures of 150 $240{ }^{\circ} \mathrm{C}$ at $4{ }^{\circ} \mathrm{C} \mathrm{min}^{-1}$, using helium carrier gas at a flow rate of $2 \cdot 3 \mathrm{ml} \mathrm{min}-1$ and a split ratio of $1: 30$. Cellular quinones were extracted with chloroform:methanol $(2: 1, \mathrm{v} / \mathrm{v})$, purified by TLC, and determined by HPLC (LC-6A; Shimadzu) with a Zorbax-ODS column $(4.6 \mathrm{~mm}$ in diameter, $250 \mathrm{~mm}$ long) and a UV detector $(275 \mathrm{~nm})$, using methanol:isopropylether $(3: 1, \mathrm{v} / \mathrm{v})$ eluent at a flow rate of $1 \mathrm{ml} \mathrm{min}^{-1}$. For DNA $\mathrm{G}+\mathrm{C}$ content, bacterial DNA was digested into nucleotides with nuclease P1 (Yamasa) and then into nucleosides with alkaline phosphatase. The relative content of both components to total nucleosides (mol\%) was estimated by HPLC using a Cosmosil C18 column $(4.6 \mathrm{~mm}$ in diameter, $150 \mathrm{~mm}$ long; Cosmo Bio), 0.2 $\mathrm{M}$ ammonium phosphate: acetonitrile $(30: 1, \mathrm{v} / \mathrm{v})$ eluent $\left(1 \mathrm{ml} \mathrm{min}^{-1}\right)$ and a UV detector $(270 \mathrm{~nm})$.

\section{RESULTS}

The phylogenetic relatedness of Moraxella-like bacteria isolated from surface seawater in the Japan Trench was studied by ML (Fig. 1) in which almost complete 16S rDNA sequence data from approved species belonging to the family Halomonadaceae was used. All five surface strains $(\mathrm{P} 1 \mathrm{H} 8, \mathrm{P} 1 \mathrm{H} 13, \mathrm{P} 1 \mathrm{H} 14$, $\mathrm{P} 1 \mathrm{H} 22$ and $\mathrm{P} 1 \mathrm{H} 25)$ were located around Halomonas aquamarina and Halomonas meridiana. Along with these known species, they made an independent clade on the Halomonas sub-branch, i.e. the former DeleyaHalomonas-Halovibrio branch, at a bootstrap probability of $91 \%$ (Fig. 1). NJ at a bootstrap probability of $82 \%$ and MP at $63 \%$ also supported this primary structure, although slightly different branching was found downstream. Pairwise distances between taxa also indicated high sequence similarities between this clade's members, $>98 \%$ in aligned $16 \mathrm{~S}$ rDNA sequences, and clear discrimination of these strains from the closest neighbour, Halomonas venusta. Based on these data, all surface strains were phylogenetically assigned as members of the Halomonas aquamarinameridiana group in the family Halomonadaceae.

Two of the five strains, $\mathrm{P} 1 \mathrm{H} 22$ and $\mathrm{P} 1 \mathrm{H} 25$, possessed weak motility as determined by microscopic observation and a cultivation experiment using semi-solid agar plates with a nutrient gradient (Table 2). After 
Table 3. DNA relatedness among Psychrobacter species and strains by DNA-DNA hybridization

The percentage homology is shown.

\begin{tabular}{|c|c|c|c|c|c|c|c|c|c|}
\hline \multirow[t]{2}{*}{ Strain } & \multirow{2}{*}{$\begin{array}{l}\text { P. immobilis } \\
{\text { ATCC } 43116^{\mathrm{T}}}\end{array}$} & \multirow{2}{*}{$\begin{array}{l}\text { P. glacincola } \\
\text { ACAM } 483^{\mathrm{T}}\end{array}$} & \multicolumn{6}{|c|}{$P$. pacificensis } & \multirow[t]{2}{*}{ E. coli } \\
\hline & & & P2J2 & P2J3 & P2J13 & $\mathbf{P}^{2} \mathbf{K}^{\mathrm{T}}$ & P2K17 & P2K18 & \\
\hline P. immobilis ATCC $43116^{\mathrm{T}}$ & 100 & 22 & 27 & 15 & 22 & 21 & 24 & 28 & 0 \\
\hline P. glacincola ACAM $483^{\mathrm{T}}$ & 16 & 100 & 17 & 9 & 12 & 14 & 14 & 22 & 0 \\
\hline P. pacificensis $\mathrm{P} 2 \mathrm{~J} 2$ & 20 & 17 & 100 & 96 & 98 & 98 & 94 & 103 & 0 \\
\hline P. pacificensis $\mathrm{P} 2 \mathrm{~J} 3$ & 8 & 6 & 94 & 100 & 91 & 90 & 85 & 100 & 0 \\
\hline P. pacificensis $\mathrm{P} 2 \mathrm{~J} 13$ & 17 & 14 & 95 & 93 & 100 & 93 & 91 & 97 & 0 \\
\hline P. pacificensis $\mathrm{P} 2 \mathrm{~K} 6^{\mathrm{T}}$ & 19 & 17 & 96 & 94 & 94 & 100 & 94 & 100 & 0 \\
\hline P. pacificensis $\mathrm{P} 2 \mathrm{~K} 17$ & 27 & 22 & 94 & 93 & 93 & 93 & 100 & 97 & 0 \\
\hline P. pacificensis $\mathrm{P} 2 \mathrm{~K} 18$ & 22 & 21 & 92 & 91 & 88 & 89 & 86 & 100 & 0 \\
\hline
\end{tabular}

EM, the presence of peritrichous flagella was confirmed for these two sluggishly motile strains (Fig. 3A, B). All five strains were also found to be halophilic, growing on $12 \% \mathrm{NaCl}$-based nutrient agar. This group of psychrophilic bacteria from surface seawater is thus characterized as aerobic, Gram-negative, nonpigmented, oxidase-positive, motile or non-motile, halophilic, rod-shaped cells-characteristic of the genus Halomonas.

All six Moraxella-like strains from deep seawater (P2J2, P2J3, P2J13, P2K66 ${ }^{\mathrm{T}}, \mathrm{P} 2 \mathrm{~K} 17$ and P2K18) were located phylogenetically on the Moraxella-Psychrobacter branch in the family Moraxellaceae, which includes the genera Moraxella, Acinetobacter and Psychrobacter (Fig. 2). The best phylogenetic tree inferred from ML showed that these strains formed a monophyletic clade separate from the Moraxella clade on the Moraxella-Psychrobacter branch at a probability of $100 \%$ (Fig. 2). This deep-sea bacterial clade could also be differentiated from the Psychrobacter clade of $P$. immobilis, $P$. urativorans, $P$. frigidicola, Psychrobacter phenylpyruvicus and $P$. glacincola, all of which, except for P. phenylpyruvicus, were widespread in Antarctic environments (Table 1). Two other topologies inferred from NJ and MP gave the same three clades on the Moraxella-Psychrobacter branch at probabilities of $100 \%$. Phylogenetically, these deepsea moraxellas appear to form a sister group to the Moraxella and Psychrobacter groups in the family Moraxellaceae.

In quantitative DNA-DNA hybridization experiments, genomic relatedness among these six deep-sea strains exceeded $85 \%$, whereas genomic relatedness was less than $30 \%$ with $P$. immobilis or P. glacincola (Table 3). Pairwise distance analysis of aligned $16 \mathrm{~S}$ rDNA sequences also showed $>97 \%$ similarity between deep-sea members, but lower similarity to any known Psychrobacter species. From these types of relatedness, the six deep-sea strains appeared to form a single independent species.
Under light microscopy, occasional and very weak motility was observed among these deep-sea strains, but no distinct motility was found in the culture experiment using semisolid agar plates (Table 2). Many fimbria-like appendages were detected around cells by EM, but no flagella were found (Fig. 3C, D). Most strains grew at $4-35^{\circ} \mathrm{C}$ in the presence of $3 \% \mathrm{NaCl}$, but produced only poor growth in the absence of $\mathrm{NaCl}$. They were not fermentative in the O-F test. The following tests were positive for all three strains studied: catalase, oxidase and urease; tolerance to $6.5 \% \mathrm{NaCl}$; and use of L-proline, L-histidine and DLmalate as sole carbon and energy sources. All strains were capable of producing acid from carbohydrates such as glucose, xylose and arabinose. Tests negative for all strains studied are shown in Table 4. In key phenotypic characteristics, these deep-sea strains were almost identical to members of the genus Psychrobacter, characterized by aerobic, Gram-negative, nonpigmented, oxidase-positive, non-motile, psychrophilic coccobacilli, but not identical in detail to any Psychrobacter phenon type (Table 4).

DNA $\mathrm{G}+\mathrm{C}$ contents determined by HPLC for three representative deep-sea strains were $44-45 \mathrm{~mol} \%$ (Table 4). Whole-cell fatty acid profiles were very

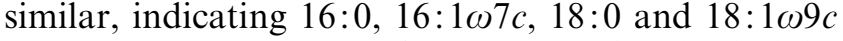
as major components (Table 5). More than half of the total content was attributable to the unsaturated fatty acid 18: $1 \omega 9 c$. The major quinone type for these strains was Q8 (Table 5).

Two other Moraxella-like strains isolated from deepsea sediments, PS2M11 and PS1M3 (Table 1), clustered on the Alteromonas branch and were finally identified as members of the genus Pseudoalteromonas with phenotypic mismatch in motility. Strains PS3M5 and PS3M26 from deep-sea sediments were on the Bacillus branch and strain P2K 5 from deep seawater was on the Vibrio branch (Table 1), indicating no contradiction between phylogenetic positions and conventional identification results. No psychrobacters were detected in isolates from deep-sea sediments. 

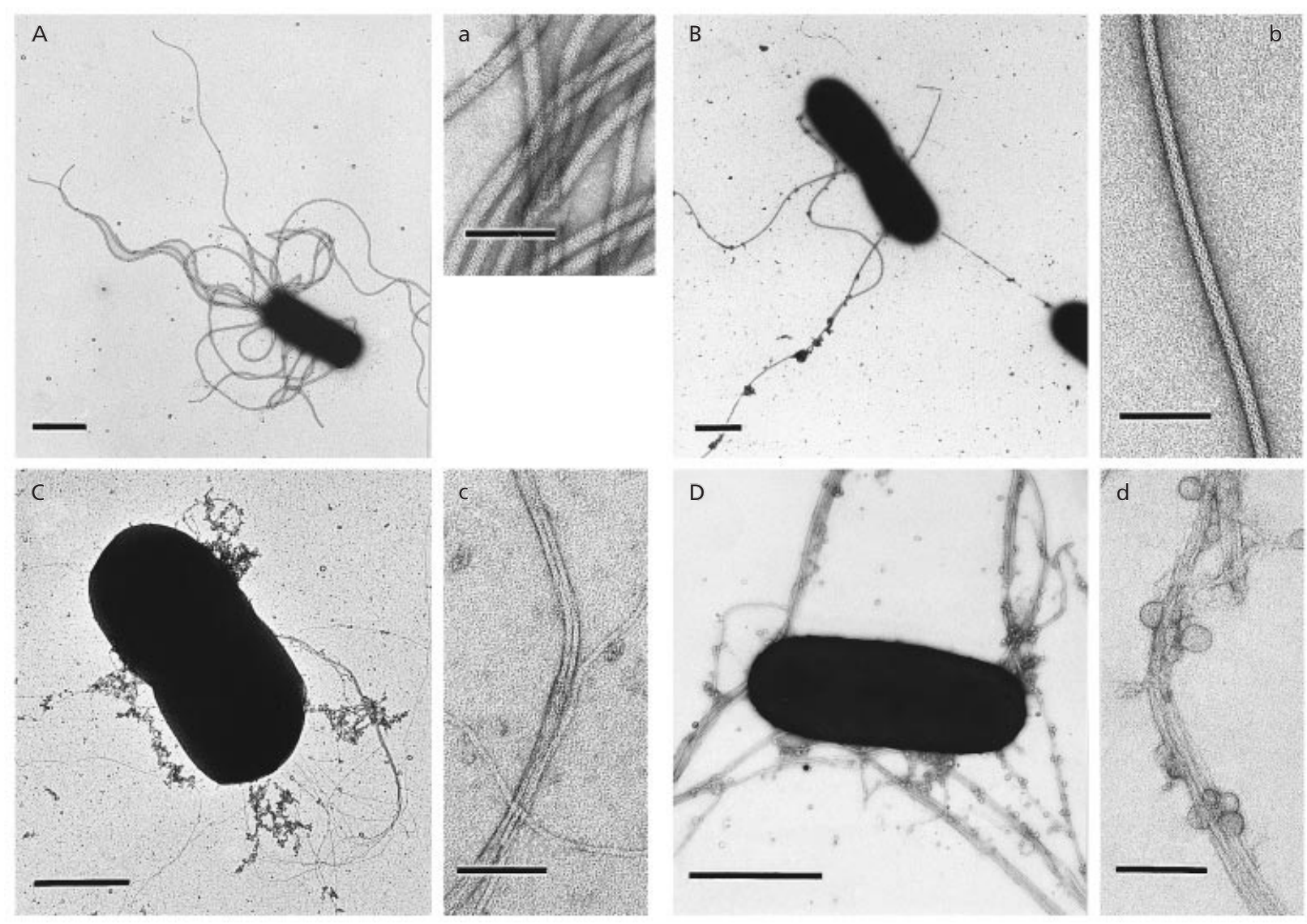

Fig. 3. Electron micrographs of psychrophilic bacteria, Halomonas sp. [A, $\mathrm{P} 1 \mathrm{H} 22$ (bar, $1 \mu \mathrm{m}) ; \mathrm{B}, \mathrm{P} 1 \mathrm{H} 25$ (bar, $1 \mu \mathrm{m})]$ from surface seawater and Psychrobacter pacificensis [C, P2J3 (bar, $1 \mu \mathrm{m}) ; \mathrm{D}, \mathrm{P} 2 \mathrm{~K} 18$ (bar, $1 \mu \mathrm{m})$ ] from deep seawater. Enlarged photos of appendages are shown for surface (flagella: $a, b$; bars, $0.1 \mu \mathrm{m}$ ) and deep-sea strains (fimbriae: $c$, d; bars, $0 \cdot 1 \mu \mathrm{m})$.

\section{DISCUSSION}

In a previous report (Maruyama et al., 1997), almost half of the psychrophilic bacteria isolated from the Japan Trench were tentatively identified as members of the Moraxella-like group. The deep-sea bacterial community was then characterized by the abundance of these moraxellas ( $>90 \%$ ), and growth-temperature experiments showed that deep-sea microbes possessed a lower predicted minimum growth temperature $\left(T_{\min }\right)$ than surface microbes at the community level, in which $T_{\min }$ is a good indicator of low-temperature adaptation by bacteria. Our study indicated that these deep-sea psychrophiles with lower $T_{\min }$ were clearly differentiated from surface psychrophiles phylogenetically, i.e. the Halomonas group from the oceanic surface water group and the Psychrobacter group from the deep seawater group.

All Moraxella-like psychrophiles from deep seawater were phylogenetically located near the Psychrobacter clade in the family Moraxellaceae, which included three genera - Moraxella, Acinetobacter and Psychrobacter (Rossau et al., 1991). Key phenotypic features of our deep-sea psychrophiles also coincided with the original description of the genus Psychrobacter, i.e. psychrophilic, Gram-negative, aerobic, oxidase-positive, non-motile and non-pigmented coccobacilli (Juni \& Heym, 1986), although no information exists about appendages. These were clearly distinct from known Psychrobacter species phylogenetically and genotypically, e.g. in tree topology, bootstrap probability, sequence similarity of $16 \mathrm{~S}$ rDNA and genomic DNA relatedness.

Significant differences between our strains and the known Psychrobacter species were also found in the following phenotypic characteristics: $\mathrm{NaCl}$ requirement for growth, acid production from carbohydrates, enzyme activities, and compounds used as sole carbon and energy sources. All Psychrobacter species are reported to grow well in a wide range of $\mathrm{NaCl}$ concentrations of 0-8\% (Bowman et al., 1996, 1997), whereas deep-sea strains seldom or never grow at an $\mathrm{NaCl}$ concentration of 0 or $8 \%$. This feature of deepsea strains appears to come from the stable salinity of the original habitat, i.e. salt concentration in the 5000-6000 m deep seawater of about 3.6\%. Unlike deep-sea strains, four of the five Psychrobacter species 
Table 4. Phenotypic characteristics of Psychrobacter pacificensis and related species

All species and strains were positive for oxidase, catalase, growth at $4-15{ }^{\circ} \mathrm{C}$, tolerance to $6.5 \% \mathrm{NaCl}$, and use of L-proline as sole carbon and energy source. The following carbon and energy sources were not used by any species or strain: $N$-acetylglucosamine, adipate, L-arabinose, caprate, L-fucose, 2-ketogluconate, 5-ketogluconate, D-glucose, myo-inositol, itaconate, maltose, D-mannitol, D-melibiose, L-rhamnose, D-ribose, salicin (D), D-sorbitol, sucrose [(D/L) showed the type of optical isomer used by Bowman et al. (1996)]. All species and strains were negative for the following (as determined by the API 20NE test): glucose fermentation, indole production, hydrolysis of aesculin and gelatin, and arginine dihydrolase. Frequency of positive strains in the P. pacificensis columns: + , positive; v, variable; - , negative; w, weak reaction. Frequency of positive strains in other columns: ,$+ 90-100 \%$ of the strains are positive; $\mathrm{v}+, 11-89 \%$ are positive and the type strain is positive; $\mathrm{v}-, 11-89 \%$ are positive and the type strain is negative;,$- 0-10 \%$ are positive. Species: $1, P$. immobilis (phenon 1$) ; 2, P$. urativorans (phenon 2 ); $3, P$. frigidicola (phenon 3); 4, P. phenylpyruvicus ACAM 535⿱乛龰 $; 5$, P. glacincola ACAM 483 ${ }^{\mathrm{T}}$.

\begin{tabular}{|c|c|c|c|c|c|c|c|c|c|}
\hline \multirow[t]{3}{*}{ Characteristic } & \multicolumn{4}{|c|}{$P$. pacificensis } & \multicolumn{5}{|c|}{ Species } \\
\hline & \multicolumn{3}{|c|}{ NIBH strain no. } & \multirow{2}{*}{$\begin{array}{l}\text { Species } \\
\text { character }\end{array}$} & \multirow[t]{2}{*}{$1 *$} & \multirow[t]{2}{*}{$2 *$} & \multirow[t]{2}{*}{$3 *$} & \multirow[t]{2}{*}{$4^{*}$} & \multirow[t]{2}{*}{$5 \dagger$} \\
\hline & P2J3 & $\mathbf{P} 2 \mathrm{KG}^{\mathrm{T}}$ & P2K18 & & & & & & \\
\hline Urease activity & + & + & + & + & $\mathrm{v}+$ & $\mathrm{v}+$ & - & + & $\mathrm{v}-$ \\
\hline Phenylalanine deaminase & - & - & - & - & + & - & + & + & - \\
\hline Tryptophan deaminase & - & - & - & - & $v-$ & - & + & - & - \\
\hline Nitrate reduction & - & - & - & - & $v-$ & $v-$ & - & - & $\mathrm{v}+$ \\
\hline \multicolumn{10}{|l|}{ Growth in $\mathrm{NaCl}(\%)$ : } \\
\hline 0 & $\mathrm{w}$ & - & - & - & + & + & + & & + \\
\hline 1 & + & - & - & $\mathrm{v}$ & + & + & + & + & + \\
\hline 3 & + & + & + & + & + & + & + & + & + \\
\hline 5 & + & + & + & + & + & + & + & + & + \\
\hline 8 & - & - & - & - & + & + & + & + & + \\
\hline \multicolumn{10}{|l|}{ Growth at $\left({ }^{\circ} \mathrm{C}\right)$ : } \\
\hline 30 & + & + & + & + & + & - & - & + & - \\
\hline 35 & + & $\mathrm{w}$ & + & + & $v+$ & - & - & + & - \\
\hline 40 & - & - & - & - & & & & & \\
\hline \multicolumn{10}{|l|}{ Acid production from: } \\
\hline D-Glucose & + & $\mathrm{w}$ & + & + & & & & & - \\
\hline D-Xylose & + & $\mathrm{w}$ & + & + & + & - & - & - & - \\
\hline D-Arabinose & + & + & + & + & + & - & - & - & - \\
\hline PNPG test & - & - & - & - & & & & & \\
\hline \multicolumn{10}{|l|}{$\begin{array}{l}\text { Use as sole carbon and energy } \\
\text { sources: }\end{array}$} \\
\hline Acetate & + & - & - & $\mathrm{v}$ & + & $\mathrm{v}+$ & + & + & + \\
\hline L-Alanine & + & - & - & $\mathrm{v}$ & + & - & - & + & $v+$ \\
\hline p-Hydroxybenzoate & - & - & - & - & - & $v-$ & - & - & \\
\hline 3-Hydroxybutyrate & + & - & + & $\mathrm{v}$ & + & + & - & + & $v+$ \\
\hline Citrate & - & - & - & - & $v-$ & - & - & + & $v+$ \\
\hline Gluconate: & - & - & - & - & $\mathrm{v}-$ & - & - & - & - \\
\hline L-Histidine & + & + & + & + & + & - & - & - & $\mathrm{v}+$ \\
\hline Lactate & + & - & + & $\mathrm{v}$ & + & $\mathrm{v}+$ & - & + & $v+$ \\
\hline Malatet & + & + & + & + & $+(\mathrm{L})$ & $\mathrm{v}+(\mathrm{L})$ & $+(\mathrm{L})$ & $+(\mathrm{L})$ & $-(\mathrm{L})$ \\
\hline Malonate & - & + & - & $\mathrm{v}$ & - & - & - & - & - \\
\hline Propionate & - & - & - & - & $v+$ & - & - & + & + \\
\hline L-Serine & - & - & - & - & - & $v-$ & - & - & - \\
\hline Suberate & + & - & - & $\mathrm{v}$ & $v-$ & - & + & - & \\
\hline$n$-Valerate & - & - & - & - & + & $v+$ & + & + & + \\
\hline Others§ & - & - & - & - & & & & & \\
\hline DNA $\mathrm{G}+\mathrm{C}$ content $(\mathrm{mol} \%)$ & 44 & 44 & 45 & $44-45$ & $44-47$ & $44-46$ & $41-42$ & 43 & $43-44$ \\
\hline
\end{tabular}

* Data from Bowman et al. (1996).

$\dagger$ Data from Bowman et al. (1997). Use of compounds was estimated with the API ID 32GN test.

$\$$ Determined by the API $20 \mathrm{NE}$ test.

$\S N$-Acetyl-D-glucosamine, m-hydroxybenzoate, glycogen and phenylacetate. 
Table 5. Fatty acid composition and major quinone type of $P$. pacificensis and P. immobilis ATCC $43116^{\top}$

$\operatorname{Tr}$, Trace amount $(<0 \cdot 1 \%)$. The major quinone type in all strains shown was Q8.

\begin{tabular}{|c|c|c|c|c|c|}
\hline \multirow[t]{3}{*}{ Composition } & \multicolumn{4}{|c|}{$P$. pacificensis } & \multirow{3}{*}{$\begin{array}{c}\text { P. immobilis ATCC } \\
43116^{\mathrm{T}}\end{array}$} \\
\hline & \multicolumn{3}{|c|}{ NIBH strain no. } & \multirow[t]{2}{*}{ Average content* } & \\
\hline & P2J3 & $\mathbf{P}^{2 K 6^{\mathrm{T}}}$ & P2K18 & & \\
\hline \multicolumn{6}{|l|}{ Fatty acid: } \\
\hline $10: 0$ & $1 \cdot 3$ & $\operatorname{Tr}$ & $1 \cdot 2$ & $0 \cdot 8(0 \cdot 7)$ & 0.9 \\
\hline $11: 0$ & $0 \cdot 1$ & $\operatorname{Tr}$ & $0 \cdot 2$ & $0 \cdot 1(0 \cdot 1)$ & $\operatorname{Tr}$ \\
\hline $12: 0$ & $2 \cdot 2$ & 0.8 & $2 \cdot 3$ & $1 \cdot 8(0 \cdot 8)$ & $\operatorname{Tr}$ \\
\hline $14: 0$ & $0 \cdot 7$ & $0 \cdot 6$ & $0 \cdot 5$ & $0 \cdot 6(0 \cdot 1)$ & $0 \cdot 3$ \\
\hline $14: 1(\mathrm{X} 1) \dagger$ & $0 \cdot 1$ & $0 \cdot 2$ & $\operatorname{Tr}$ & $0 \cdot 1(0 \cdot 1)$ & $0 \cdot 1$ \\
\hline $15: 0$ & $0 \cdot 4$ & $\operatorname{Tr}$ & $0 \cdot 4$ & $0 \cdot 3(0 \cdot 2)$ & $0 \cdot 2$ \\
\hline $16: 0$ & $7 \cdot 3$ & $8 \cdot 7$ & $6 \cdot 5$ & $7 \cdot 5(1 \cdot 1)$ & $4 \cdot 3$ \\
\hline $16: 1(\omega 7 c)$ & $9 \cdot 7$ & $15 \cdot 8$ & $6 \cdot 6$ & $10 \cdot 7(4 \cdot 7)$ & $3 \cdot 8$ \\
\hline $16: 1(\mathrm{X} 2) \dagger$ & $0 \cdot 4$ & $0 \cdot 4$ & $0 \cdot 3$ & $0 \cdot 4(0 \cdot 1)$ & 0.4 \\
\hline $17: 0$ & $2 \cdot 7$ & $5 \cdot 6$ & $4 \cdot 8$ & $4 \cdot 4(1.5)$ & $4 \cdot 2$ \\
\hline i17:0 & $0 \cdot 6$ & $\operatorname{Tr}$ & $0 \cdot 4$ & $0 \cdot 3(0 \cdot 3)$ & $\operatorname{Tr}$ \\
\hline $17: 1(\mathrm{X} 3) \dagger$ & $5 \cdot 1$ & 1.5 & $5 \cdot 1$ & $3 \cdot 9(2 \cdot 1)$ & $6 \cdot 8$ \\
\hline $18: 0$ & $9 \cdot 4$ & 5.6 & $13 \cdot 1$ & $9 \cdot 4(3 \cdot 8)$ & $8 \cdot 0$ \\
\hline $18: 1(\omega 7 c)$ & $1 \cdot 2$ & $0 \cdot 8$ & $0 \cdot 7$ & $0 \cdot 9(0 \cdot 3)$ & 0.8 \\
\hline $18: 1(\omega 9 c)$ & $50 \cdot 1$ & $52 \cdot 8$ & $50 \cdot 9$ & $51 \cdot 3(1 \cdot 4)$ & $63 \cdot 1$ \\
\hline $18: 2$ & $3 \cdot 4$ & $2 \cdot 4$ & $1 \cdot 8$ & $2 \cdot 5(0 \cdot 8)$ & $3 \cdot 5$ \\
\hline 19:0 & $0 \cdot 4$ & $0 \cdot 4$ & $0 \cdot 6$ & $0 \cdot 5(0 \cdot 1)$ & 0.9 \\
\hline $20: 0$ & $\operatorname{Tr}$ & $\operatorname{Tr}$ & $\operatorname{Tr}$ & $\operatorname{Tr}$ & $0 \cdot 1$ \\
\hline Total & $95 \cdot 1$ & $95 \cdot 6$ & $95 \cdot 4$ & $95 \cdot 5$ & $97 \cdot 4$ \\
\hline Total unsaturated & $70 \cdot 0$ & $73 \cdot 9$ & $65 \cdot 4$ & $69 \cdot 8$ & $75 \cdot 0$ \\
\hline \multicolumn{6}{|l|}{ Hydroxy fatty acid: } \\
\hline 3-OH 12:0 & $4 \cdot 1$ & $3 \cdot 6$ & $3 \cdot 9$ & $3 \cdot 9(0 \cdot 3)$ & $2 \cdot 2$ \\
\hline $3-\mathrm{OH}$ 14:0 & 0.8 & $0 \cdot 8$ & $0 \cdot 7$ & $0 \cdot 8(0 \cdot 1)$ & 0.4 \\
\hline Total & $4 \cdot 9$ & $4 \cdot 4$ & $4 \cdot 6$ & $4 \cdot 6(0 \cdot 3)$ & $2 \cdot 6$ \\
\hline
\end{tabular}

* Numbers in parentheses are standard deviations $(n=3)$.

$\dagger \mathrm{X} 1-\mathrm{X} 3$, exact double bond positions are not known.

(P. urativorans, $P$. frigidicola, $P$. glacincola and $P$. phenylpyruvicus) cannot produce acid from carbohydrates, and $P$. immobilis is positive in tests for phenylalanine deaminase and $n$-valerate use (Table 3 ). From this evidence, a new species, Psychrobacter pacificensis, is proposed for these deep-sea strains.

Ecologically, it is worth noting that almost the same phylogenetic and phenotypic group of bacteria dominated in extremely cold, remote environments such as the Antarctic surface and Japan Trench deep seawater. Other than the temperature similarity, does any close relationship exist between the two environments? Since a major but very slow deep water current is known to run constantly toward the Japan Trench from the Antarctic Ocean (Stommel, 1958), it is highly probable that some micro-organisms in Japan Trench deep seawater originate in polar regions such as the Antarctic Ocean. After the entrainment of Antarctic microbes from the surface to the deep sea via the sinking of cooled seawater and/or faecal pellets excreted by zooplankton, further selection and evolution may occur in the deep-ocean current directed toward the Japan Trench. This hypothesis is also supported by the physiological characteristics of such deep-sea bacteria, i.e. cell membranes adapting to low temperatures at least partially preadapt to high hydrostatic pressure (Delong \& Yayanos, 1985, 1986). Other than having biotechnological applicability such as useful lipids and enzymes, marine bacteria such as deep-sea psychrobacters could be indicators for evaluating global deep-ocean circulation, regional upwelling and food chains in the ocean.

As shown by Boivin-Jahns et al. (1995), who studied many bacterial isolates from deep-underground water both phenotypically and phylogenetically, more attention must be paid to motility tests in the conventional identification of Gram-negative, aerobic, oxidase-positive, non-pigmented bacteria. Our study 
on marine bacteria also indicates that phylogenetic analysis has great advantages in the rapid, precise identification and classification of bacteria whose motility is obscure. Both motile and non-motile Halomonas strains were found in surface seawater and many fimbriae were observed in deep-sea psychrobacters. Since bacterial fimbriae are considered to correlate with cell attachment and gene transformation (in the latter case, called pili), occasional, very weak motility may be attributable to these appendages (Henrichsen, 1972). The relationship between motility and fimbria attachment has not yet been well characterized, but such very weak 'twitching motility' has been reported for different types of bacteria (Henrichsen, 1975), including Moraxella and Acinetobacter species (Krieg \& Holt, 1984). Such appendages may contribute to cell flotation, flocculation and particle formation in nature, and flotation appears to favour the movement of these psychrobacters in the deepocean current. Further comprehensive studies on marine, polar and deep subsurface bacteria at the molecular phylogenetic level should present new findings in microbial systematics and in the adaptation, evolution and dispersion of microbes.

\section{Description of Psychrobacter pacificensis sp. nov.}

Psychrobacter pacificensis (pa.ci.fi.cen'sis. M.L. adj. pacificensis pertaining to the Pacific Ocean).

Strains are aerobic, Gram-negative, non-motile, nonpigmented, non-sporulating, oxidase-positive, catalase-positive coccobacilli $1.0-1.5 \mu \mathrm{m}$ long and about $1 \mu \mathrm{m}$ wide. Strains produce many fimbriae as appendages, but no flagella. Circular, convex, offwhite colonies with a complete edge occur on agar plates containing polypeptone and yeast extract. No fluorescent pigments form. Seawater or $\mathrm{NaCl}$ at about $3 \%$ is required for optimal growth, with most strains not growing at 0 or $8 \% \mathrm{NaCl}$. It takes $1-2$ weeks to reach the stationary phase at $4{ }^{\circ} \mathrm{C}$, but isolates give growth yields at $4{ }^{\circ} \mathrm{C}$ comparable to those at $20^{\circ} \mathrm{C}$. Optimal growth occurs at about $25^{\circ} \mathrm{C}$, with the maximum growth temperature being $38^{\circ} \mathrm{C}$. Acid is formed aerobically from glucose, xylose and arabinose. Urease is positive, but phenylalanine deaminase and tryptophan deaminase are negative. The species is negative for the following biochemical tests: glucose fermentation, indole production, aesculin hydrolysis and gelatin and arginine dihydrolase. Strains use Lhistidine and DL-malate as sole carbon and energy sources. Some strains use acetate, L-alanine, 3hydroxybutyrate, lactate, malonate and suberate, but none use $p$-hydroxybenzoate, citrate, gluconate, propionate, L-serine or $n$-valerate. The major fatty acid is $18: 1 \omega 9 c$ and $\mathrm{Q} 8$ is the major quinone. DNA $\mathrm{G}+\mathrm{C}$ content is $43-44 \mathrm{~mol} \%$ as determined by HPLC. The type strain is NIBH P2K6 $6^{\mathrm{T}}\left(=\mathrm{IFO} 16270^{\mathrm{T}}\right)$, isolated at $4{ }^{\circ} \mathrm{C}$ from $6000 \mathrm{~m}$ deep seawater in the Japan Trench off Hachijo Island, Japan.

\section{ACKNOWLEDGEMENTS}

This work was part of an Industrial Science and Technology Frontier Program supported by the Agency of Industrial Science and Technology, Japan. We thank Project Leader Ryuichiro Kurane, NIBH, for supporting the marine microbiological study. Thanks are also due to S. Yoshida, Japan Food Research Laboratories, for biochemical examination, and $\mathrm{K}$. Kawasaki and H. Kanazaki, NIBH, for electron microscopy observation.

\section{REFERENCES}

Adachi, J. \& Hasegawa, M. (1996). Computer science monographs, no. 28. MOLPHY version 2.3 - programs for molecular phylogenetics based on maximum likelihood. Tokyo: Institute of Statistical Mathematics.

Akaike, H. (1974). A new look at the statistical model identification. IEEE Trans Automat Contr AC 19, 716-723.

Boivin-Jahns, V., Bianchi, A., Ruimy, R., Garcin, J., Daumas, S. \& Christen, R. (1995). Comparison of phenotypical and molecular methods for the identification of bacterial strains isolated from a deep subsurface environment. Appl Environ Microbiol 61, 3400-3406.

Bøvre, K. \& Henriksen, S. D. (1976). Minimal standards for description of new taxa within the genera Moraxella and Acinetobacter: proposal by the subcommittee on Moraxella and allied bacteria. Int J Syst Bacteriol 26, 92-96.

Bowman, J. P., Cavanagh, J., Austin, J. J. \& Sanderson, K. (1996). Novel Psychrobacter species from Antarctic ornithogenic soils. Int $J$ Syst Bacteriol 46, 841-848.

Bowman, J. P., Nichols, D. S. \& McMeekin, T. A. (1997). Psychrobacter glacincola sp. nov., a halotolerant, psychrophilic bacterium isolated from Antarctic sea ice. Syst Appl Microbiol 20, 209-215.

Delong, E. F. \& Yayanos, A. A. (1985). Adaptation of the membrane lipids of a deep-sea bacterium to changes in hydrostatic pressure. Science 228, 1101-1103.

Delong, E. F. \& Yayanos, A. A. (1986). Biochemical function and ecological significance of novel bacterial lipids in deep-sea procaryotes. Appl Environ Microbiol 51, 730-737.

Dobson, S. J. \& Franzmann, P. D. (1996). Unification of the genera Deleya (Baumann et al. 1983), Halomonas (Vreeland et al. 1980), and Halovibrio (Fendrich 1988) and the species Paracoccus halodenitrificans (Robinson and Gibbons 1952) into a single genus, Halomonas, and placement of the genus Zymobacter in the family Halomonadaceae. Int J Syst Bacteriol 46, 550-558.

Ezaki, T., Hashimoto, Y. \& Yabuuchi, E. (1989). Fluorometric DNA-DNA hybridization in microdilution wells as an alternative to membrane filter hybridization in which radioisotopes are used to determine genetic relatedness among bacterial strains. Int J Syst Bacteriol 39, 224-229.

Felsenstein, J. (1981). Evolutionary trees from DNA sequences: a maximum likelihood approach. $J$ Mol Evol 17, 368-376.

Felsenstein, J. (1995). PHYLIP (Phylogeny Inference Package) and manual, version 3.57c. Department of Genetics, University of Washington, Seattle, WA, USA.

Fitch, W. M. (1971). Toward defining the course of evolution: minimum change for a specific tree topology. Syst Zool 20, 406-416. 
Hasegawa, M. \& Kishino, H. (1994). Accuracies of the simple methods for estimating the bootstrap probability of a maximum likelihood tree. Mol Biol Evol 11, 142-145.

Hasegawa, M., Kishino, H. \& Yano, T. (1985). Dating of the human-ape splitting by a molecular clock of mitochondrial DNA. J Mol Evol 22, 160-174.

Henrichsen, J. (1972). Bacterial surface translocation: a survey and a classification. Bacteriol Rev 36, 478-503.

Henrichsen, J. (1975). The occurrence of twitching motility among Gram-negative bacteria. Acta Pathol Microbiol Scand Sect B 83, 171-178.

Holt, J. G., Krieg, N. R., Sneath, P. H., Staley, J. T. \& Williams, S. T. (editors) (1994). Gram-negative aerobic/microaerophilic rods and cocci. In Bergey's Manual of Determinative Bacteriology, 9th edn, pp. 71-174. Baltimore: Williams \& Wilkins.

Juni, E. \& Heym, G. A. (1980). Transformation assay for identification of psychrophilic achromobacters. Appl Environ Microbiol 40, 1106-1114.

Juni, E. \& Heym, G. A. (1986). Psychrobacter immobilis gen. nov., sp. nov.: genospecies composed of Gram-negative, aerobic, oxidase-positive coccobacilli. Int J Syst Bacteriol 36, 388-391.

Kester, D. R., Duedall, I. W., Connors, D. N. \& Pytkowicz, R. M. (1967). Preparation of artificial seawater. Limnol Oceanogr 12 , 176-179.

Kimura, M. (1980). A simple method for estimating evolutionary rates of base substitutions through comparative studies of nucleotide sequences. J Mol Evol 16, 111-120.

Kishino, H., Miyata, T. \& Hasegawa, M. (1990). Maximum likelihood inference of protein phylogeny and the origin of chloroplasts. J Mol Evol 31, 151-160.

Krieg, N. R. \& Holt, J. G. (editors) (1984). Genus Moraxella and genus Acinetobacter. In Bergey's Manual of Systematic Bacteriology, vol. 1, pp. 296-307. Baltimore: Williams \& Wilkins.

Kusunoki, S., Ezaki, T., Tamesada, M., Hatanaka, Y., Asano, K., Hashimoto, Y. \& Yabuuchi, E. (1991). Application of colorimetric microdilution plate hybridization for rapid genetic identification of 22 Mycobacterium species. J Clin Microbiol 29, $1596-1603$.

Lane, D. L. (1991). 16S/23S rRNA sequencing. In Nucleic Acid Techniques in Bacterial Systematics, pp. 115-175. Edited by E. Stackebrandt \& M. Goodfellow. Chichester: Wiley.

Maruyama, A., Maeda, M. \& Simidu, U. (1986). Occurrence of plant hormone (cytokinin)-producing bacteria in the sea. $J$ Appl Bacteriol 61, 569-574.

Maruyama, A., Maeda, M. \& Simidu, U. (1990). Distribution and classification of marine bacteria with the ability of cytokinin and auxin production. Bull Jpn Soc Microb Ecol 5, 1-8.

Maruyama, A., Mita, N. \& Higashihara, T. (1993). Particulate materials and microbial assemblages around the Izena black smoking vent in the Okinawa Trough. J Oceanogr 49, 353-367.

Maruyama, A., Taniguchi, R., Tanaka, H., Ishiwata, H. \& Higashihara, T. (1997). Low-temperature adaptation of deep-sea bacteria isolated from the Japan Trench. Mar Biol 128, 705-711.
Murray, M. G. \& Thompson, W. F. (1980). Rapid isolation of high molecular weight plant DNA. Nucleic Acids Res 8, 4321-4325.

Prieto, M., Garcia-Armesto, M. R., Garcia-Lopez, M. L., Otero, A. \& Moreno, B. (1992). Numerical taxonomy of Gram-negative, nonmotile, nonfermentative bacteria isolated during chilled storage of lamb carcasses. Appl Environ Microbiol 58, 2245-2249.

Rossau, R., Van Landschoot, A., Gillis, M. \& De Ley, J. (1991). Taxonomy of Moraxellaceae fam. nov., a new bacterial family to accommodate the genera Moraxella, Acinetobacter, and Psychrobacter and related organisms. Int J Syst Bacteriol 41, 310-319.

Rüger, H.-J. (1989). Benthic studies of the northwest African upwelling region: psychrophilic and psychrotrophic bacterial communities from areas with different upwelling intensities. Mar Ecol Prog Ser 57, 45-52.

Saitou, N. \& Nei, M. (1987). The neighbor-joining method: a new method for reconstructing phylogenetic trees. Mol Biol Evol 4, 406-425.

Shaw, B. G. \& Latty, J. B. (1988). A numerical taxonomic study of nonmotile nonfermentative Gram-negative bacteria from foods. J Appl Bacteriol 65, 7-21.

Shewan, J. M., Hobbs, G. \& Hodgkiss, W. (1960). The Pseudomonas and Achromobacter groups of bacteria in the spoilage of marine white fish. J Appl Bacteriol 23, 463-468.

Simidu, U., Kaneko, E. \& Taga, N. (1977). Microbiological studies of Tokyo Bay. Microb Ecol 3, 173-191.

Simidu, U., Taga, N., Colwell, R. R. \& Schwartz, J. R. (1980). Heterotrophic bacterial flora of the seawater from the Nansei Shoto (Ryukyu Retto) area. Bull Jpn Soc Sci Fish 46, 505-510.

Simidu, U., Kogure, K., Fukami, K. \& Imada, C. (1986). Heterotrophic bacterial flora of the Antarctic ocean. Mem Natl Inst Polar Res Japan (Spec Issue) 40, 405-412.

Smibert, R. M. \& Krieg, N. R. (1994). Phenotypic characterization. In Methods for General and Molecular Bacteriology, pp. 607-654. Edited by P. Gerhardt, R. G. E. Murray, W. A. Wood \& N. R. Krieg. Washington, DC: American Society for Microbiology.

Stommel, H. (1958). The abyssal circulation. Deep-Sea Res $\mathbf{5}$, $80-82$.

Suzuki, M. \& Yamasato, K. (1986). Factors affecting the viability of L-dried cells and frozen cells of marine bacteria. Jpn J Freez Dry 32, 39-46 (in Japanese).

Thompson, J. D., Higgins, D. G. \& Gibson, T. J. (1994). CLUSTAL $\mathrm{W}$ : improving the sensitivity of progressive multiple sequence alignment through sequence weighting, position-specific gap penalties, and weight matrix choice. Nucleic Acids Res 22, $4673-4680$

Van de Peer, Y., Jansen, J., De Rijk, P. \& De Wachter, R. (1997). Database on the structure of small ribosomal subunit RNA. Nucleic Acids Res 25, 111-116.

Yamasato, K., Akagawa, M., Oishi, N. \& Kuraishi, H. (1982). Carbon substrate assimilation profiles and other taxonomic features of Alcaligenes faecalis, Alcaligenes ruhlandii, and Achromobacter xylosoxidans. J Gen Appl Microbiol 28, 195-213. 